\title{
What Can China Learn From the Composition of CFIUS?
}

\author{
Chan-ting Chen \\ Business School, East China University of Political Science and Law, Shanghai, China \\ chenchanting@126.com
}

\begin{abstract}
China imitated U.S.'s CFIUS review and established the ministerial joint conference to undertake its own foreign investment national security review in 2011. Yet regulation on the ministerial joint conference is inadequate. An in-depth study of the composition of CFIUS finds that Chinese joint conference could make progress at several aspects. A detailed explanation of the potential conference members will make the review process more transparent. The Leadership of the Standing Committee of the Political Bureau or the Chairman would enhance the authority of the national security review. The single supervision mode is recommended to avoid potential conflict of interests among conference members. And the head of involved departments is more suitable to be regulated as the members of the joint conference.

Index Terms - CFIUS, the Joint Conference, Foreign Investment National Security Review, U.S., China
\end{abstract}

\section{Introduction}

China followed the U.S. foreign investment national security review to establish its own review mechanism for inbound foreign investment along with the release of the Circular of the General Office of the State Council on the Establishment of Security Review System Regarding Mergers and Acquisitions of Domestic Enterprises by Foreign Investors (hereinafter to be referred as NSR Circular) and the Provisions of the Ministry of Commerce on the Implementation the Security Review System for Mergers and Acquisitions of Domestic Enterprises by Foreign Investors (hereinafter to be referred as NSR Provisions). The ministerial joint conference for security review of merger and acquisition of domestic enterprises by foreign investors (hereinafter referred to as the joint conference) is established to specifically implement the security review of mergers and acquisitions. However, the NSR Circular only says that the joint conference is under the leadership of the State Council and led by the National Development and Reform Commission (hereinafter to be referred as NDRC) and the Ministry of Commerce, without specifying other members of the joint committee. Detailed regulation on the constitution is wanting. Since The Committee on Foreign Investment in the United States (hereinafter to be referred as CFIUS) is the prototype of the joint conference, this article analyses the Composition of CFIUS and brings forward suggestions on the improvement of the joint conference.

\section{The Composition of the CFIUS Reflects the Checks and Balances among Involved Members.}

The preamble to FINSA says that the purpose of the Act is " $[\mathrm{t}] \mathrm{o}$ ensure national security while promoting foreign investment and the creation and maintenance of jobs [and] to reform the process by which such investments are examined for any effect they may have on national security."[1] This statement illustrates that the nature of the foreign investment national security review is to keep the balance between economic interests brought by the inbound investment and its potential negative effect to the national security. CFIUS is responsible to carry out national security review and investigation within the context of U.S. open investment policy. How does CFIUS fulfil this obligation? The composition of CFIUS reflects the check and balance among involved members. (Fig. 1)

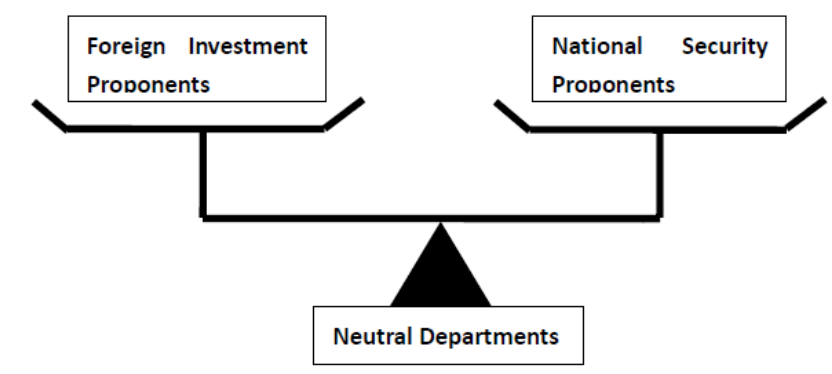

Fig.1 the checks and balances among involved members of CFIUS

FINSA for the first time establishes CFIUS's statutory position to carry out the national security review. The Act also prescribes that the Committee shall be comprised of nine members, namely the Secretary of the Treasury, the Secretary of Homeland Security, the Secretary of Commerce, the Secretary of Defense, the Secretary of State, the Attorney General of the United States, the Secretary of Energy, the Secretary of Labor and the Director of National Intelligence.[2] After the enumeration, the Act includes a miscellaneous clause, saying that the President, when he determines appropriate, is entitled to add the heads of any other executive department, agency, or office generally or on a case-by-case basis. According to this clause, and also vested by the Constitution, the President enact the Executive Order 11858 (as amended by Executive Order 13456) to add the following member into the Committee: the United States Trade Representative, the Director of the Office of Science and Technology Policy, the Director of the Office of Management and Budget, the Chairman of the Council of Economic Advisers, the Assistance to the President for National Security Affairs, the Assistant to the President for Economic Policy and the Assistant to the President for Homeland Security and Counterterrorism. [3] The Executive Order further empowers the Secretary of the Treasury to include the heads of other related executive departments in the CFIUS review process on a case-by-case basis.[4] All these members can be divided into three groups, the FDI proponents, the national security proponents, and neutral members. 
FDI proponents prefer a loose national security review of foreign takeovers as they are more focused on promoting the country's economic benefits and bilateral relationship between the United States and foreign countries. They are departments dealing with the country's finance, economic and foreign relations issues, including the Secretary of Treasury, the Secretary of Commerce, the Secretary of State, the U.S. Trade Representative, the Assistant to the President for Economic Policy, the Director of the Office of Management and Budget and the Chairman of the Council of Economic Advisers. Members advocating more protection to national security include the Secretary of Defence, the Attorney General, the Secretary of Homeland Security, and the Assistant to the President for National Security Affairs, Assistant to the President for Homeland Security and Counterterrorism, Secretary of Energy, and Director of the Office of Science and Technology Policy, which belongs to the group of national security proponents. (Fig. 2) With seven members focusing on economic and commercial issues, and another seven members concentrating on national security, the composition of CFIUS demonstrates that the Committee itself is a good model of check and balance between the economic influence and national security impact that might brought by foreign investments.

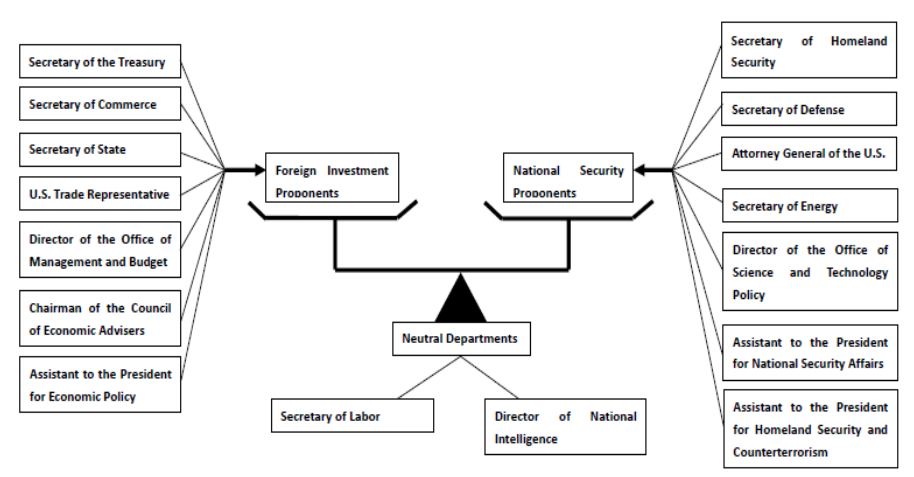

Fig.2 the group of national security proponents

FINSA added another two nonvoting and ex officio members, the Secretary of Labor and Director of National Intelligence, into the member list. The Secretary of Labor is included in the reviewer group to check foreign investors' compliance with U.S. employment rules.[5] The Director of National Intelligence involves the CFIUS process to provide information from a number of different sources that CFIUS needs during any national security review.[6] These two new members, especially the participation of the Director of National Intelligence, indicates that U.S. will review foreign investment more thoroughly and professionally with the help of the U.S. intelligence community.

\section{CFIUS Composition is a Good Model for Joint Conference.}

\section{A. More Regulation on the Composition of the Joint Conference is Necessary.}

The purpose for China to establish the foreign investment national review mechanism is the same as FINSA, to balance the economic benefits and national security concerns that might brought by the cross-border investment. A proof is the preamble of the NSR Circular. ${ }^{1}$ It confirms the positive role of foreign investors in China's development, and states plainly that the circular is made for maintaining a better order for inbound M\&As. A full picture of the joint committee will make the review mechanism more transparent and encourage more foreign investors to enter the Chinese market. Therefore, it is suggested that the law should enumerate related departments to be members of the joint committee. There might be a long time to go for Chinese government to give the member list until the time is ripe, for China is still a green hand in manipulating the security review. During the exploratory stage, it is worthwhile to study CFIUS and FINSA for Chinese foreign investment national security review mechanism mimics its U.S. counterpart to a great extent.

\section{B. Higher Level Leadership is Necessary to Enhance the Authority of Foreign Investment National Security Review The leadership style of CFIUS is recommended. The} Committee is under the leadership of the President to make sure that the state authority center can directly control inbound foreign investment. The U.S. president is the head of state as well as the head of the federal government, with much more substantial powers other than executive power. While in China, the joint conference is under the leadership of the State Council, the highest organ of State administration and the highest executive organ of State power. Comparing the leaderships of the joint conference and CFIUS, the latter enjoys a higher authority. Considering the fact that the national security is functioned as the last resort to protect the country's security in the investment domain, a high level of leadership is necessary. Therefore, it would be suggested to put the joint conference under the leadership of the Standing Committee of the Political Bureau. Or, because CFIUS works as the President's task force assessing foreign M\&As' impact in the state's security, China might modify its U.S. counterpart to put the joint conference under the direct leadership of the Chairman, working as his task force.

\section{The Single Supervision Mode is Required to Reduce Potential Conflict Between Joint Conference Members}

CFIUS is chaired by the Secretary of the Treasury. One reason is that the original function of CFIUS was only to monitor the economic implications of foreign investment in the United States and did not have a national security component when President Ford firstly created the Committee

\footnotetext{
1 "With the in-depth development of economic globalization and the further expansion of China's opening up in recent years, the investment made by foreign investors through merger and acquisition has been on the gradual increase, which has promoted the diversified utilization of foreign investment in China and played a positive role in optimizing the allocation of resources, promoting technical progress, improving business management level and other aspects. To guide the orderly development of mergers and acquisitions of domestic enterprises by foreign investors and safeguard national security, upon the approval of the State Council, you are hereby notified of the relevant matters on the establishment of a security review system for mergers and acquisitions of domestic enterprises by foreign investors as follows..." http://english.mofcom.gov.cn/aarticle/policyrelease/domesticpolicy/201103/2 0110307430493.html (last visited Jan. 23, 2015).
} 
in 1975.[7] The Secretary of Treasury continued its leadership in CFIUS after it was given a new role by Exon-Florio. Critics attribute CFIUS failure to properly limit the inflow of foreign to Treasury's chair of the Committee for the first priority of the Treasury is to be friendly to foreign investors to ease the financial pressure brought by the enormous size of the U.S. budget and current account deficits.[8] Though the validity for the Secretary of Treasury continues to preside over CFIUS after the Committee is given a new role in the post ExonFlorio era continues to be challenged, FINSA stipulates in black and white that "[t]he Secretary of the Treasury shall serve as the chairperson of the Committee." [9] This is because that the value of FINSA is to deter suspicious foreign business activities and to restructure some potential transactions in order to balance the country's economic benefit and national security, instead of simply barring the incoming foreign capital.

The joint conference is supervised by the NDRC and the Ministry of Commerce. In other words, both these two departments are co-responsible for the daily operation of the joint conference. The dual supervision mode may bring unnecessary function overlap and power struggle. The main functions of the NDRC are to study and formulate policies for national economic and to maintain the balance of economic development and national economic security. [10] The Ministry of Commerce is responsible to promote domestic and foreign trade, foreign investment and international economic cooperation. [11] Though their functions overlap and interweave in part, the NDRC would be a better one to be in charge of the joint conference. Because the NDRC plays a major role in monitoring healthy development of the country's economy and maintaining the balance of economic development and national security concern, which tallies with the purpose of national security review and the function of the joint conference.

\section{The Notion of "Lead Agency" is Suggested to Make the National Security Review More Professional}

FINSA introduce the notion of "Lead Agency", which means that the Secretary of the Treasury should designate a member or members of CFIUS to be the lead agency or agencies for each covered transaction. [12] The "Lead Agency" mechanism is a stone that achieves two aims. Firstly, it helps the Treasury to fulfill its mission of guarding the country's security in foreign investment domain. With the help of the lead agency, CFIUS review now is more professional and to the point. Secondly, the mechanism also avoids potential conflict of power among CFIUS members if there would be a new chairperson for the Committee. The "Lead Agency" mechanism hence is recommended for the joint conference, to replace the dual supervision of the conference.

\section{It Is Better that the Joint Conference Consists of the Head of the Involved Departments}

Both FINSA and the Executive Order 11858, when stipulating the composition of CFIUS, include the head of related agencies as the Committee's member, instead of the agencies themselves. This regulation indicates that CFIUS is an inter-agency committee consisting of cabinet level members. Several advantages could be found by this regulation. First, cabinet level staffs keep an intimate relationship with the President in their routine work. So that CFIUS essentially is a quasi-cabinet ad hoc meeting solely focusing on the assessment of inbound M\&As. Second, the foreign M\&As national security review, deliberately ambiguous in its regulations, is made to be the last resort controlling inbound FDI. The reviewers are endowed with great discretion to evaluate a covered case from various perspectives, including politics and international relationships. Only those directors of involved organs are able to exercise this discretion. Meanwhile, due to the involvement of classified information on business, political and military affairs, the reviewers and decision makers should be limited to a minority of high rank governmental officials. Third, the devise, to include head of involved departments as the Committee members, saves administrative costs. The head of each department, within their own divisions, is the person in charge and the center of the power. Staffs of involved departments may attend the review process to undertake specific investigations, while the Secretaries of departments are the ones that make final decisions based on acquired information.

As for the joint conference review in China, the word "conference" could be "a large formal meeting where a lot of people discuss important matters such as business or politics, especially for several days", or "a private meeting for a few people to have formal discussions".[13] The NSR Circular regulates that the joint conference, together with pertinent departments, conducts security review of M\&As by foreign investors under the leadership of the State Council and led by the NDRC and the Ministry of Commerce.[14] The literal sense of the regulation is that staffs of the related departments will involve in the joint conference deliberation. In this case, the conference will refer to a formal meeting with a lot of people attending. This may not be the legislative intent since the review is an economically and politically sensitive matter. A better interpretation of the regulation would be that a lot of people may take part in the investigation process, yet only a few key persons should be involved in the conference deliberation. Therefore, it is suggested to follow FINSA to stipulate that the joint conference consists of the head of the involved departments.

\section{Summary}

The establishment of the foreign investment national security review system is the first step for Chinese government to keep a good balance between the economic interests and national security in the post financial crisis era. The next step will be to improve the mechanism. Though the joint conference is set up specifically to undertake the security review, relative regulations do not give a precise explanation on the constitution of the joint conference. The unclearness may bring non-transparency and rent-seeking during the review process, and discourage potential investors. Therefore, a prompt and thorough study on the constitution of the joint 
conference is necessary. The U.S. CFIUS will be a good model for China to follow, for its composition nicely reflecting the nature of national security review, and also for the U.S. CFIUS review itself is the prototype of the foreign investment national security review in China.

\section{References}

[1] Foreign Investment and National Security Act of 2007, available at http://www.treasury.gov/resource-center/international/foreigninvestment/Documents/FINSA.pdf (last visited Feb. 9, 2015).

[2] 50 USC App. 2170 (k)

[3] Executive Order 11858 (as amended by Executive Order 13456), Sec. 3.

[4] Executive Order 11858 (as amended by Executive Order 13456), Sec. 3. (b) (iii).

[5] Treasury Department Issues Final CFIUS Regulations Implementing Exon-Florio Amendment, http://www.bingham.com/Media.aspx?MediaId=7887 (last visited Apr. 23, 2009).
[6] 50 USC App. 2170 (b) (4) (A).

[7] See Exec. Order No. 11858, 3A C.F.R. 160 (1975), reprinted in 15 U.S.C. $\S 78 b$ note (2000).

[8] Susan J. Tolchin, Halting the Erosion of America's Critical Assets, National Academy of Science Issues in Science \& Technology, Mar. 22, 1993, Vol. V9, No. N3, at 65. Jeremy David Sacks, Monopsony and the archers: rethinking foreign acquisitions after Thomson-LTV, Law and Policy in International Business, Mar. 22, 1994, Vol. 25, No. 3, at 1019.

[9] 50 USC App. 2170 (k) (3).

[10] Main Functions of the NDRC, available at http://en.ndrc.gov.cn/mfndrc/ (last visited Jan. 26, 2015).

[11] Mission of Ministry of Commerce, available at http://english.mofcom.gov.cn/column/mission2010.shtml (last visited Jan. $26,2015)$.

[12] 50 USC App. 2170 (k) (5).

[13] Longman Dictionary of Contemporary English, p. 280, Foreign Language Teaching and Research Press, 2002.

[14] NSR Circular, III (II) 